\title{
KESESUAIAN LAHAN TANAMAN KARET (Hevea brasiliensis) DI DESA GIRI NANTO KABUPATEN SELUMA
}

\author{
${ }^{1)}$ Chaula Lutfia S, ${ }^{2}$ Fauzul Azhimah \\ ${ }^{1)}$ Program Studi Agroteknologi Fakultas Pertanian Universitas Quality Berastagi \\ ${ }^{2)}$ Program Studi Agribisnis Fakultas Pertanian Universitas Quality Berastagi \\ Email : chaulalutfia@yahoo.com
}

\begin{abstract}
Abstrak
Sumber daya lahan merupakan sumber daya alam yang sangat penting bagi kelangsungan hidup manusia karena sumber daya alam diperlukan dalam setiap kehidupan. Evaluasi lahan merupakan taksiran kesesuaian untuk penggunaan lahan tertentu guna mengoptimalkan lahan yang ada pada suatu daerah.Penelitian ini bertujuan untuk menilai kelas kesesuaian lahan pengembangan tanaman karet dalam upaya pelestarian lingkungan di Desa Giri Nanto Kabupaten Seluma. Penelitian dilakukan pada tahun 2015 dengan metode survei bebas, dianalisis secara diskriptif kualitatif dan kuantitatif melalui pendekatan analisis mengenai dampak lingkungan dan dipetakan melalui analisis menggunakan software Arc.Gis 10.0, satuan peta tanah, dan kriteria kesesuaian lahan karet dengan skala peta 1:85.000. Hasil penelitian menunjukkan bahwa luas total lahan potensial di kawasan Desa Giri nanti adalah 1.185 ha. Sebaran kelas kesesuaian lahan potensial tanaman karet sebagian besar adalah kelas lahan S2 (cukup sesuai) meliputi 622,82 ha $(8,9 \%)$, kelas S3 (sesuai marginal) meliputi 526,4 ha $(7,5 \%)$, dan kelas lahan $\mathrm{N}$ (tidak sesuai) meliputi 35,68 ha $(0,5 \%)$. Adapun faktor pembatas pada kelas kesesuaian lahan potensial S3 (sesuai marginal) yaitu kemiringan lereng 16-30\%, dan kelas $\mathrm{N}$ (tidak sesuai) yaitu tekstur tanah kasar. Membiarkan lahan tertutup pada kemiringan lereng $>40 \%$, dan tekstur tanah kasar sebagai kawasan hutan lindung diharapkan dapat berfungsi sebagai salah satu alternatif konservasi lahan untuk pelestarian lingkungan secara berkelanjutan.
\end{abstract}

Kata kunci : karet, kesesuian lahan potensial, pelestarian lingkungan

Abstract

Land resources are natural resources that are very important for human survival because natural resources are needed in every life. Land evaluation is an estimate of suitability for a particular land use in order to optimize the existing land in an area. This study aims to assess the suitability class of rubber plantations in environmental conservation efforts in Giri Nanto Village, Seluma Regency. The study was conducted in 2015 with a free survey method, analyzed descriptively qualitatively and quantitatively through an analysis approach to environmental impact and mapped through analysis using Arc.Gis software 10.0, land map units, and rubber land suitability criteria with a map scale of 1: 85,000. The results showed that the total area of potential land in the Giri Village area would later be 1,185 ha. The distribution of potential land suitability classes for 
rubber plants was mostly S2 land classes (quite suitable) covering $622.82 \mathrm{ha}$ (8.9\%), S3 class (marginal suit) covering 526.4 ha (7.5\%), and land classes $N$ (incompatible) covers $35.68 \mathrm{ha}(0.5 \%)$.The limiting factor for the potential S3 land suitability class (according to marginal) is 16-30\% slope, and class $N$ (not suitable), namely rough soil texture. Allowing closed land to slope $>40 \%$, and the texture of coarse soil as a protected forest area are expected to function as an alternative to sustainable land conservation for environmental conservation.

Keywords: rubber, potential land suitability, environmental preservation. 


\section{PENDAHULUAN}

Pembangunan perkebunan karet berperanpenting dalam pelestarian lingkungan danmendorong pertumbuhan sentra-sentra ekonomi baru diwilayah pengembangan.Sebagian besar wilayah Indonesia memiliki karakteristik lahan yang sesuai dengan syarat tumbuh tanaman karet. Pada umumnya areal pertanaman karet tersebar diwilayahSumatera $\quad(71,19 \%)$ dan Kalimantan(24,45\%). Total lahan perkebunan karet nasional tercatat mencapai 3,56 juta $\mathrm{Ha}$, dimana 85,09\% diantaranya merupakan perkebunan rakyat, $6,91 \%$ perkebunan besar negara dan 7,95\% perkebunan besar swasta (Badan Pusat Statistik, 2014). Produksi karet alam nasional pada tahun 2014 mencapai sekitar 3,23 juta ton. Sebanyak71,03\% diantaranya berasal dari Sumatera dan 21,59\% berasal dari Kalimantan (BPS, 2014).

Di Provinsi Bengkulu karet merupakankomoditiprimadona keduabagimasyarakat Kabupaten Seluma. Dengan luas mencapai 113.040 hektar dan produksi 86.146 ton karet kering.Pertumbuhan produksi karet untuk Indonesia dapat dicapai melalui peremajaan atau penanaman baru karet yang cukup besar, dengan perkiraan produksi pada tahun 2020 sebesar 3.5 juta ton dan tahun 2035 sebesar 5.1 juta ton (Anwar, 2001).

Umumnya tanaman karet tumbuh optimum pada dataran rendah dengan ketinggian $200 \mathrm{~m}$ dpl. Ketinggian lebih dari $600 \mathrm{~m}$ dpl tidak tidak cocok untuk pertumbuhan tanamankaret. Perbedaan ketinggian tempat akan mempengaruhi suhu, tingkat pencahayaan dan curah hujan pada tanaman karet (Setyamidjaja, 1993).Faktor iklim seperti cahaya, suhu, kecepatan angin dan curah hujan mempengaruhi pertumbuhan fisik dan mutu lateks tanaman karet yang dihasilkan.

Budidaya pengembangan tanaman karet sangat erat kaitannya dengan daya dukung lahan sebagai media tanam komoditi ini. Besarnya pengaruh kesesuaian lahan untuk mendukung pertumbuhan tanaman akan berpengaruh secara langsung terhadap produktivitas tanaman (Pangudijatno, 1981).

Selain itu, tanaman karet juga berfungsi dalam memperbaiki lingkungan seperti rehabilitasi lahan, mencegah erosi dan banjir, mengatur tata guna air, dan menciptakan iklim yang sehat dan bebas polusi. Menurut Azwar, et al. (1989), energi yang dihasilkan tanaman karet, berupa oksigen, kayu, dan biomassa dapatdigunakan untuk mendukung fungsi perbaikan lingkungan. Secara alami, tanaman karet setiaptahun mengalami gugur daun yang mampu menyuburkantanah. Daur hidup yang demikian akan terus berulangselama satu siklus tanaman karet, paling tidak selama 30tahun. Oleh karena itu, keberadaan tanaman karet sangatstrategis bagi kelangsungan kehidupan, karena tanamanini mampu berperan sebagai penyimpan dan sumberenergi.

Pertumbuhan dan perkembangan tanaman karet sangat dipengaruhi oleh faktor-faktor iklim, tanah, jenis tanaman (klon),dan faktor pengelolaan yang semuanya saling berkaitan erat satu dengan yang lain.Pengembangannya disuatu daerah selain didasari oleh potensilahan, jugamempertimbangkan kondisi penggunaan lahan yang ada. Adapun penelitian ini bertujuan untuk menilaikelaskesesuian lahan terhadap pengembangan tanaman karet dalam upaya pelestarian lingkungansecara berkelanjutan berdasarkan parameter kondisi lahan, topografi, ketersediaan air, suhu dan ordo tanah dan karakteristik tanaman karet di Desa Giri Nanto. 


\section{METODE PENELITIAN}

Penelitian ini dilaksanakan di Desa Giri Nanto, Kecamatan Ulu talo, Kabupaten Seluma dengan potensi luas lahan 1.185 ha Pada ketinggian tempat berkisar antara 100-300 m dpl, dan bentuk topografi bergelombang sampai berbukit. Penelitian telah dilaksanakan pada tahun 2015.

Metode yang digunakan dalam penelitian ini adalah metode survey bebas dengan menggunakan analisis deskriptif baik secara kualitatif maupun kuantitatif. Menurut Abdullah (1993) metode bebas atau metode satuan lahan merupakan metode survey dengan cara pengamatan berdasarkan satuan lahan yang telah dibuat dan di cek kebenarannya. Berdasarkan FAO (1976) Hasil dari perbandingan tersebut akan didapatkan tingkat kesesuaian lahan yang, meliputi kelas S1 (sangat sesuai), kelas S2 (cukup sesuai), kelas S3 (sesuai marjinal), $\mathrm{N}$ (tidak sesuai).

Metode penyusunan peta analisis menggunakan software Arc.Gis 10.0 untuk mendapatkan satuan peta tanah (SPT). Pengamatan, pengukuran, dan pencatatan dilapangan dilakukan pada titik sampel yang ditentukan secara sistematis sampling (Pengambilan sampel sesuai dengan satuan peta lahan) dengan jarak 500 $\mathrm{m}$ x $500 \mathrm{~m}$, selanjutnya data diolah dengan analisis proximity dan overlay, kawasan Desa Giri Nanto, kemiringan lereng, tinggi tempat. Dari hasil overlay peta tersebut, dihasilkan peta jenis tanah, kesesuaian lahan, beserta peta faktor pembatas. Jumlah titik sampel dilapangan yang disurvey sebanyak 23 titik sampel dan 2 titik sampel untuk membuat profil tanah.
Pembuatan profil dilakukan untuk mendapatkan data deskripsi tanah. Selanjutnya dilakukan analisis deskriptif apakah dilakukan perbaikan dari sifat fisik atau sifat kimia tanah agar kelas kesesuaian lahan aktual meningkat menjadi kelas kesesuaian lahan potensial untuk tanaman karet

\section{HASIL PEMBAHASAN Nanto \\ Kondisi lahan Desa Giri}

Luas arealDesa Giri secara administratif yaitu 1.185 ha yangmasih merupakan areal hijauan baik berupa hutan, perkebunan rakyat, kebun campuran, semak belukar, sawah, dan pertanian tanah kering. Pengembangan pemanfaatan tanaman karet di suatu desa merupakan salah satu cara untuk meningkatkan produktifitas pertanian dan kesejahteraan masyarakat desa. Secara umum kegiatan pengembangan daerah tersebut meliputi juga pengenalan pola pertanian secara tepat, dan sesuai dengan potensi lahannya. Potensi lahan perlu dijabarkan secarabaik agar dapat digunakan sesuai dengan rencanapengembangannya(Abdullah, 199).

\section{Kondisi Topografis}

Desa Giri Nanto mempunyai ketinggian (elevasi) bervariasi dari 100-300 m dpl, dan bentuk wilayah topografi bervariasi dari bergelombang sampai berbukit. Wilayah bergelombang dengan lereng $8-16 \%$ seluas 622,82 ha, dan berbukit $16-30 \%$ seluas 105,25 ha.

Sangadji (2001) menyatakan bahwa ketinggian tempat berhubungan dengan suhu dan kelembaban, semakin tinggi suatu 
tempat maka suhu akan semakin rendahdan kelembaban semakin tinggi. Hal ini yang dapat menyebabkan lateks akan lebih cepat membeku sehingga hasil lateks yang dihasilkan akan lebih rendah.

\section{Martono(2004)menambahkan} bahwa lereng yang semakin curamdan semakin panjang akan meningkatkan besarnya erosi, jika lereng semakin curam maka kecepatan aliran permukaan meningkat sehingga daya angkutnya juga meningkat. Kartasapoetra, dkk (1987) mengatakan bahwa salah satu upaya untuk mengurangi bahaya erosi pada kemiringan lahan adalah dengan cara pembuatan teras.

\section{Kondisi Ketersediaan Air}

Berdasarkan data curah hujan yang digunakantipe iklim daerah Kabupaten Seluma menurut Oldeman, bertipe iklim C2, dengan 6 bulan basah berturut-turut (curah hujan rata-rata $>200$ $\mathrm{mm} /$ bulan) dan 3 bulan kering berturut-turut (curah hujan rata-rata $<100 \mathrm{~mm} /$ bulan). Secara garis besar memiliki curah hujan $(\mathrm{CH})$ rataan $\pm 3.300 \mathrm{~mm} /$ tahun dalam periode 5 tahun (2010-2015).

\section{Berdasarakan}

kriteria kesesuaian iklim untuk tanaman karet yang mengacu pada penelitian Djaenudin et al.,(2003), kemudian dicocokkan dengan syarat tumbuh tanaman karet maka ketersediaan air yang meliputi curah hujan dan bulan kering di desa Giri Nanto masuk kategorikelas S2 (cukup sesuai) yaitu > 3000-3500 mm dan lamanya masa kering 2-3 bulan.

Susetyo \& Hadi, (2012) yang menyatakan bahwa kondisi kelas S2merupakan suatu lahan cukup sesuai untuk pengembangan komoditas karet sebab kondisi tanah dan iklim mendukung maka tanaman akan mampu menghasilkan produktivitas yang baik.

\section{Kondisi Suhu}

Suhu berpengaruh terhadap aktivitas fisiologis tumbuhan antara lain, buka tutup stomata, laju transpirasi, laju penyerapan air dan nutrisi, fotosintesis dan respirasi. Suhu yang rendah menghambat pertumbuhan, karena laju fisiologi tumbuhan berjalan lambat sehingga menghambat pertumbuhan (Wulan, $S$ 2012). Suhu udara di Indonesia sangat dipengaruhi oleh tinggi tempat.Prawito (2009) mengemukakan bahwa gradien suhu udara di Bengkulu hanya sebesar $0,29^{\circ} \mathrm{C}$ tiap ketinggian naik $100 \mathrm{~m}$ dpl. Suhu udara diperoleh dari perhitungan hubunganantara suhu dengan ketinggian tempat menggunakan rumus Braak (1929). Berdasarkan data dari titiktitikstasiun cuaca, suhu udara di desa Giri Nanto rata-rata berkisar antara $23^{\circ}-25^{\circ} \mathrm{C}$, hal ini termasuk pada kriteria kesesuaian S2 (cukup sesuai).

\section{Kondisi Tanah}

Kondisi tanah yang sesuai dengan

pertumbuhankaretdalampenelitianini diperoleh dari klasifikasi tanah dalam satuan peta tanah (SPT) kemudian diturunkan nama ordo jenis tanah tersebut.Penyebaran jenis tanah yang dominan ditemui didesa Giri Nanto adalah Inceptisols, dan Ultisol dengan luasan Inceptiso 1823,31 ha $(69,52 \%)$ dan Ultisol 360,92 ha $(30,47 \%)$ Tanah tersebut tersebar bervariasi pada Fisiografi dataran, bergelombang dan perbukitan. 
Pada pengamatan Profil I berdasarkan sistem klasifikasi soil Taxonomy. Tanah inceptisol mulai berkembang, yang sedang mengalami perkembangan horison. Berdasarkan hasil analisis laboratorium tanah pada Horison A dengan kedalaman tanah 0-30 cm memiliki kejenuhan basa sebesar $22,35 \%$ (rendah), KTK 25 me/100g (tinggi), tekstur tanah lempung berdebu (liat 61,49\%; debu 27,74\%; pasir 10,78\%). Pada horison $\mathrm{Bw}$ kedalaman tanah 30-60 cm memiliki kejenuhan basa sebesar 21,34\% (rendah), KTK 21 Me/100g (Sedang), tekstur tanah lempung berdebu (liat $62,84 \%$; debu 25,18\%; pasir 11,98\%). Pada Horison C kedalaman tanah > $60 \mathrm{~cm}$ memilikikejenuhan basa sebesar $11,63 \%$ (sangat rendah), KTK tanah $19 \mathrm{Me} / 100 \mathrm{~g}$ (sedang), tekstur tanah sandy clay loam (liat 27,07\%, debu $22,72 \%$, pasir 50,21\%).

Dari 19 titik SPT yang diamati dilapangan, tanah inceptisol memiliki tekstur beragam dari kasar hingga halus, draenase baik, bentuk wilayah beragam dari berombak hingga berbukit,dataran rendah umumnya solum tebal/dalam, sedangkan pada titik sampel yang lereng (curam) solumnya agak tipis. kedalaman tanah dangkal hingga dalam, batuan permukaan tanah ratarata sedang (5-15\%), tingkat bahaya erosi sedang, dan memiliki tingkat kesuburan tanah yang rendah. Berdasarkan hasil analisis dari laboratorium sifat kimia tanah Corganik beragam berkisar $(0,23 \%$ $6,7 \%$ ) dari tingkat sangat rendah sampai sangat tinggi. N-organik beragam berkisar $(0,09-0,30 \%)$ tingkat rendah sampai sedang, (P2O52,47-15,55 ppm) tingkat sangat rendah sampai rendah, $\mathrm{K}$
(0,13-0,37 me/100g) tingkat sangat rendah, dan $\mathrm{pH}$ tanah $(4,0-4,7)$ tingkat sangat masam sampai masam. KTK tanah beragam dari 9,8-22,5 me/100g tingkat rendah sampai sedang. Hal ini sesuai dengan literatur Munir (1996) inceptisol terdapat pada daerah-daerah yang berlereng gelombang sampai curam, dan draenase buruk. Tanah ini bersolum dangkal, bahkan ditemukan bahan induknya menyembul kepermukaan tanah, sehingga mengakibatkan perakaran tanaman di atasnya sangat terbatas, permukaan tanah juga mudah tererosi yang mengakibatkan unsur hara mudah tercuci, sehingga tanah miskin unsur hara.

Pada pengamatan Profil II berdasarkan sistem klasifikasi soil Taxonomy. Dari 5 titik SPT sampel yang diamati dilapangan ultisol memiliki tekstur dari sedang hingga halus, draenase baik, bentuk wilayah beragam dari datar hingga berbukit,kedalaman tanah dalam, batuan permukaan tanah rata-rata sedang (0-5\%), tingakat bahaya erosi sedang sampai berat, dan memiliki tingkat kesuburan tanah yang rendah.

$\begin{array}{ccc}\text { Ciri } & \text { morfologi } & \text { Ultisol } \\ \text { berdasarkan } & \text { hasil } & \text { analisa }\end{array}$ laboratorium tanah tanah pada horison A dengan kedalaman tanah 0-25 cm memiliki kejenuhan basa sebesar 25,75\% (rendah), KTK 18 me/100g (sedang), tekstur tanah lempung beliat (liat 16,69\% ; debu $22,55 \%$; pasir $60,76 \%$ ). Pada horison $\mathrm{Bt}$ kedalaman tanah 25-70 cm memiliki kejenuhan basa sebesar 21,61\% (Rendah), KTK 16 Me/100g (Sedang), tekstur tanah clay loam (liat 40,12\% ; debu 28,89\%; pasir 30,99\%). Pada Horison C kedalaman tanah > $70 \mathrm{~cm}$ memiliki kejenuhan basa sebesar $14,50 \%$ (sangat rendah), 
KTK tanah $14 \mathrm{Me} / 100 \mathrm{~g}$ (rendah), tekstur tanah liat berdebu (liat $42,39 \%$, debu 43,98\%, pasir $13,63 \%)$.

Berdasarkan hasil analisis dari laboratorium sifat kimia tanah dari 5 titik sampel yaitu C-organik beragam berkisar $(1,92-5,65 \%)$ tingkat rendah sampai tinggi. N-organik beragam berkisar $(0,09-0,25 \%)$ tingkat rendah sampai sedang. P2O5beragam (4,61 - 25,50 ppm) tingkat sangat rendah sampai sedang, K (0,10-0,29 me/100g) tingkat sangat rendah, dan $\mathrm{pH}$ tanah $(4,5-$ $5,0)$ tingkat masam. KTK tanah beragam dari 14,44 - 19,23 me/100g tingkat rendah sampai sedang. Hal ini sesuai dengan literatur Hakim, dkk (1986) bahwa ciri-ciri morfologi tanah ultisol reaksi tanah masam, Kejenuhan Al tinggi, berwarna kuning kecoklatan hingga merah, tekstur tanah dari bahan induk kapur, batu andesit cenderung halus seperti liat, struktur tanah sedang hingga kuat, KTK rendah, kadar bahan organik rendah, kandungan hara rendah, dan kejenuhan basa rendah.

Berdasarkan literatur Tala'ohu, dkk. (1996) bahwa Inseptisol dan Ultisol peka terhadap erosi dan kesuburan tanah rendah. Pengelolaan tanaman pada tanah Inseptisol dan Ultisol perlu dimulai sejak awal pembukaan lahan dan penanaman yakni dengan memperhatikan kaidah-kaidah konservasi tanah dan air. Salah satu cara yang dapat dilakukan adalah pengelolaan $\mathrm{pH}$ tanah, karena salah satu faktor kimia yang paling penting mempengaruhi pelepasan unsur hara dari larutan tanah yaitu $\mathrm{pH}$ tanah. Adapun upaya teknologi yang dapat diterapkan yaitu penambahan bahan organik, pemupukan, penanaman penutup tanah, dan pengaturan tata air.

\section{Kesesuaian lahan untuk Tanaman Karet di desa Giri Nanto}

Persyaratan kriteria kesesuaian lahan untuk tanaman karet yang mengacu pada penelitian Djaenudin et al.,(2003), Persyaratan kondisi lahan yang sesuai untuk pertumbuhan karet adalah curah hujan $2500-3000 \mathrm{~mm}$, suhu $26-30^{\circ} \mathrm{C}$ berdrainase cukup baik, dengan tekstur agak halus dengan lereng $<8 \%$ dan bahaya erosi rendah. Kemiringan tanah (lereng) erat kaitannya dengan bahaya erosi, makin curam lereng tersebut semakin tinggi pula bahaya erosi yang ditimbulkan.

Berdasarkan Tabel.1 terlihat bahwa kelas kesesuaian lahan di Desa Giri Nanto terdapat tiga kelas kesesuian tanahyaitu Kelas lahan S2 (cukup sesuai) meliputi 622,82 ha (8,9\%), kelas S3 (sesuaimarginal) meliputi 526,4 ha (7,5\%), dan kelas lahan $\mathrm{N}$ (tidaksesuai) meliputi 35,68 ha $(0,5 \%)$.

Tabel 1. Luas Potensi Pengembangan Tanaman Karet Berdasarkan Kesesuaian lahan di Desa Giri Nanto

\begin{tabular}{ccc}
\hline Kelas Lahan & \multicolumn{2}{c}{ Luas } \\
\cline { 2 - 3 } Actual & $\mathrm{Ha}$ & $\%$ \\
\hline $\mathrm{S} 2$ & 622,82 & 8,9 \\
$\mathrm{~S} 3 \mathrm{w}$ & 526,4 & 7,5 \\
$\mathrm{Nt}$ & 35,68 & 0,5 \\
\hline Total & $1.184,90$ & 16,9 \\
\hline
\end{tabular}




\section{Keterangan : $\mathrm{w}=$ kemiringan lereng \\ $\mathrm{t}=$ tekstur tanah}

Untuk pertumbuhan tanaman karet pada lahan kelas S2 cukup sesuai untuk pengembangan karet, karena untuk mendapatkan tanaman karet yang dapat tumbuh dengan baik dan menghasilkan lateks yang optimal maka harus diperhatikan syarat iklim dan lingkungan yang diinginkan tanaman. Hal ini sesuai dengan literatur Pangudijatno (1981) yang menyatakan bahwa besarnya pengaruh kesesuaian lahan untuk mendukung pertumbuhan tanaman akan berpengaruh secara langsung terhadap produktivitas tanaman.

Pada lahan kelas kesesuaian lahan S3 (sesuai marginal) faktor pembatas syarat tumbuhtanaman karet yaitu kemiringan lereng 16$30 \%$ meliputi 526,4 ha $(7,5 \%)$. Adapun upaya-upaya dalam mengatasi faktor pembatastersebut adalah melalui teknik konservasi tanah dan air dengan menggunakan metode vegetatif dan mekanik dan pengelolaan pemupukan yang efektif.Hal ini sesuai dengan literatur Martono (2004) yang menyatakan bahwalereng yang semakin curam dan semakin panjang akan meningkatkan besarnya erosi, jika lereng semakin curam maka kecepatan aliran permukaan meningkat sehingga dayaangkutnya juga meningkat. Kartasapoetra, dkk (1987 juga menyatakan bahwa salah satu upaya untuk mengurangi tingkat bahaya erosi pada kemiringan lahan adalah dengan cara pembuatan teras.

Berdasarkan hasil survey di Desa Giri Nanto, ditemukan kelas kesesuian lahan kelas $\mathrm{N}$ (tidak sesuai) seluas 35,68 ha $(0,5) \%$ dengan faktor pembatas tekstur tanah kasar.Tekstur tanah yang kasar tidak cocok untuk budidaya tanaman karet karena rentan cekaman kekeringan, leaching (pencucian hara oleh erosi) dan kapasitas menahan air rendah sehingga pertumbuhan akar menjadi buruk. Hal ini sesuai dengan Darussamin, dkk (2011) menyatakan bahwa kawasan yang memiliki laju erosi tinggi dipengaruhi oleh curah hujantinggi, aliran permukaan, kelerengan yang curam, penutupan lahan dan kondisi tekstur/keadaan perakaran tanah yang buruk. Selain itu berdasarkan Setiawan dan Andoko (2008) jika persyaratan tidak terpenuhi, tanaman karet bisa saja tumbuh, tetapi pertumbuhannya lambat. Tanaman karet bisa saja menjadi kerdil dan kurus dengan percabangan banyak. Lebih buruk lagi, produksi lateks rendah sehinggasecara ekonomis tidakmenguntungkan, meskipun dilakukan perawatan secara intensif, tetap produktivitasnya rendah.Oleh karena itu, dalam pengembangan tanaman karet dikawasan desa Giri Nanto kelas lahan yang tidak sesuai (N) disarankan untuk tidak dilakukan pembukaan lahan, sebaiknya membiarkan lahan tertutup sebagai hutan konservasi.

\section{KESIMPULAN}

Hasil penelitian ini menunjukkan bahwa ordo tanah yang ditemukan dikawasan desa Giri Nanto Kabupaten Seluma yaitu Inceptisol dan Ultisol.

Sebaran kelas kesesuaian
lahan potensial tanaman karet
sebagian besar adalah kelas S2
(cukup sesuai) meliputi seluas
622,82 ha $(8,9 \%)$, kelas S3 (sesuai
marginal) seluas 526,4 ha $(7,5 \%)$,


kelas lahan $\mathrm{N}$ (tidak sesuai) seluas 35,68 ha $(0,5 \%)$.

Faktor pembatas kelas S3 dan $\mathrm{N}$ di kawasan desa Giri Nanto yaitu kelas S3 dengan kemiringan lereng $16-30 \%$ seluas 526,4 ha $(7,5 \%)$, dan faktor pembatas kelas $\mathrm{N}$ yaitu tekstur tanah kasar meliputi 35,68 ha.

\section{DAFTAR PUSTAKA}

1. Abdullah, T. S, 1993.Survey Tanah dan Evaluasi lahan. Penebar swadaya, Jakarta.

2. Anwar, C. 2001. Managemen dan Teknologi Budidaya Karet. Pusat Penelitian Karet. Medan.

3. Azwar, R., Aidi-Daslin, I. Suhendry, and S.Woelan.2000.Quantifyin ggenetical and environmental factors in determining rubber cropproductivity. Proc. Ind. Rubb. Conf. and IRRDB Symp., Bogor,12-14 September 2000.

4. Badan Pusat Statistik. (2014). Statistik Karet Indonesia 2014. Jakarta, Indonesia: BPS.

5. Darussamin. A., M. Astuti., N. Prastiwi., D. Rahardian., A. Prawoto., L.Th. Siregar, Husnawati, dan Hikman, 2011. Buku Panduan Pelatihan Fasilitas Prinsip dan Kriteria Produksi Minyak Sawit Berkelanjutan RSPO untuk Petani. Indonesian Smallholders Working Group (INA-SWG).

6. Djaenudin $\mathrm{D}$, Marwan $\mathrm{H}$, Subagyo H, Mulyani A dan Suharta N. 2003.

$\begin{array}{lr}\text { Kriteria } & \text { Kesesuaian } \\ \text { Lahan } & \text { untuk } \\ \text { Komoditas } & \text { Pertanian. } \\ \text { Pusat Penelitian } & \text { Tanah } \\ \text { dan } & \text { Pengembangan } \\ \text { Agroklimat. } & \text { Badan } \\ \text { Penelitian } & \text { dan } \\ \text { Pengembangan } & \text { Pertanian. } \\ \text { Departemen } & \text { Pertanian. } \\ \text { Bogor. } & \end{array}$

7. FAO. 1976. A Framework for Land Evaluation. Soil Resources Management and Conservation Service Land and Water Development Division. FAO Soil Bulletin No. 32. FAO-UNO, Rome

8. Hakim. N, M. Y. Nyakpa, A. M. Lubis, S. G. Nugroho, M. A. Diha, G. B. Hong, dan H. H. Bailey, 1986. Dasar-Dasar Ilmu Tanah. Penerbit Universitas Lampung. Lampung.

9. Hendrick dan Berthwick dalamWulan, S. 2012. Faktor Lingkungan Yang Mempengaruhi

Pertumbuhan Tanaman. http:// myrealact.

Blogspot. com. Diakses 25 februari 2013.

10. Kartasapoetra, G., A. G. Kartasapoetra dan M. M. Sutedjo. 1987. Teknologi Konservasi Tanah dan Air. Bina Aksara, Jakarta.

11. Martono. 2004. Pengaruh Intensitas Hujan dan Kemiringan Lereng Terhadap Laju Kehilangan Tanah Pada Tanah Regosol Kelabu. Tesis.Universitas Diponegoro, Semarang. 
12. Pangudijatno, G., 1981. Penilaian teknis kemampuan Lahan untuk Budidaya Karet dan Kelapa Sawit. Proc. Konprensi Budidaya Karet dan Kelapa Sawit, Medan.

13. Prawito, P. 2009. Hasil Riset Aksi Rehabilitasi Lahan Kritis dengan Sumber Daya Lokal di Bengkulu. Sumatera. Benang merah. Yogyakarta.

Barat. diakses dari http://balittanah.litbang.p ertanian.go.id/ind/dokum entasi/prosiding2008pdf/ sidik.pdf pada tanggal 5 februari 2017.

19. Komoditasunggulan bengkulu. , http://pedomanbengkulu. com/2016/03/5komoditas-unggulanperkebunan-bengkulu/ (diakses tanggal 17 mei 2019)

14. Sangadji, S. 2001. Pengaruh Iklim Tropis di Dua Ketinggian Tempat yang Berbeda Terhadap Potensi Hasil Tanaman Soba (Fagopyrum esculentum Moench.). Tesis. IPB, Bogor.

15. Setiawan dan Andoko . 2008. Petunjuk Lengkap Budidaya Karet. Agro Media Pustaka . Jakarta. 37-39 hal

16. Susetyo, I., \& Hadi, H. (2012). Pemodelan produksi tanaman karet berdasarkan potensi klon, tanah, dan iklim. Jurnal Penelitian Karet, 30(1), 23-35.

17. Munir, M. 1996. Tanah-Tanah Utama Indonesia. Karakteristik, Klasifikasi, dan pemanfaatnnya. Pustaka Jaya.

18. Tala'ohu, S. H., D. Subardja, dan Alkasuma. 2008.

Kondisi Biopisik dan

Arahan Teknologi

Konservasi Tanah pada

Perkebunan Kelapa

Sawit di Daerah Sungai

Landak, Kabupaten

Landak, Kalimantan 